\title{
O. Andrzej A. Napiórkowski OSPPE, Proegzystencja Kościoła, Wydawnictwo WAM, Kraków 2018, ss. 203
}

Na rynku wydawnictw teologicznych ukazała się książka o. prof. Andrzeja Napiórkowskiego, zatytułowana Proegzystencja Kościoła (Kraków 2018). Autor, który kieruje Katedrą Eklezjologii na Wydziale Teologicznym Uniwersytetu Papieskiego Jana Pawła II w Krakowie, dokonuje w niej ciekawej i dość nowatorskiej interpretacji misji, duchowości, a przede wszystkim istoty Kościoła, odnosząc się do jego proegzystencji.

Wolumin składa się z sześciu rozdziałów, które poświęcone są kolejno poszczególnym zagadnieniom. Pierwszy (ss. 13-63) opisuje proegzystencję Kościoła w złożonej rzeczywistości religijnej i społecznej, następny (ss. 65-93) poświęcony jest procesowi powstawania Kościoła. Rozdziały trzeci i czwarty mówią o misteryjności (ss.95-118) i eucharystyczności zbawczego posłannictwa Kościoła (ss. 119-141). Piątą część monografii (ss. 143-171) autor poświęca roli Maryi we wspólnocie eklezjalnej. W ostatnim rozdziale (ss. 173-191) opisuje zagadnienie monastycyzmu w świetle mariologii i maryjności. Na podstawie krótkich opisów rozdziałów można zauważyć, że Autor przyglądając się fenomenowi Kościoła czerpie zarówno z teologii dogmatycznej jak i fundamentalnej, co pozwala mu całościowo spojrzeć na Kościół jako wspólnotę duchowo-ludzką.

Ojciec Andrzej Napiórkowski w przystępnej formie wyjaśnia odbiorcy zagadnienia dotyczące powstawania Kościoła. Ta wspólnota przez całe wieki urzeczywistniała się jako powszechny sakrament Zbawienia i nieustannie przekraczała poznawalne empirycznie granice. Warte zauważenia jest podejście autora do Kościoła jako eucharystycznej 
wspólnoty zjednoczonej na wzór Trójcy Świętej. Jako cechy tej wspólnoty są wyakcentowane misyjność, chrystocentryzm i orientacja eschatologiczna.

$\mathrm{Na}$ początku monografii czytelnik będzie miał możliwość zapoznania się z różnymi aspektami współczesnych zagrożeń płynących z laickości, fundamentalizmu islamskiego, ale i wewnątrzkościelnego chaosu. Na podstawie tych opisów ukazuje wartość rodziny jako Kościoła domowego. Zauważa, że wielką wartość ma kościelna misja oraz proegzystencja Chrystusa i Ducha Świętego.

W drugim rozdziale zajmuje się procesem powstawania Kościoła. Wyjaśniając jego genezę ukazuje na pozaczasową ideę Boga Ojca w relacji do Kościoła, następnie opisuje etap Kościoła w perspektywie konstytuowania się Izraela jako Ludu Bożego do momentu wyłonienia się nowego ludu w Jezusie Chrystusie. Podkreśla ustanowienie Kościoła przez Jezusa poprzez akty eklezjotwórcze, które Mu towarzyszyły od ustanowienia Wspólnoty Dwunastu aż po popaschalne chrystofanie. Nie omija perspektywy Kościoła, która wyłania się z podstawowego charakteru nauczania Jezusa, koncentrującego się na zagadnieniu Królestwa Bożego. Finalizuje te refleksje ukazując Kościół spełniający się od Pięćdziesiątnicy ukierunkowując jego misję na eschatologiczną pełnię w perspektywie wieczności.

Trzeci rozdział monografii w sposób niezwykle klarowany ukazuje współczesną, posoborową eklezjologię. Tłumaczy zagadnienie Kościoła jako misterium Zbawienia, które autor umieszcza w kontekście poglądów wielu teologów (np. K. Rahner, J. Ratzinger, Z. Kubacki) na temat relacji chrześcijaństwa do innych religii, a także aspektu przynależności do Kościoła i Zbawienia.

Ważne jest ukazanie największej tajemnicy wiary Kościoła katolickiego, jaką jest sakrament Eucharystii, któremu poświęca kolejny rozdział niniejszej książki. Refleksja nad tym zagadnieniem ma charakter chronologiczno-egzegetyczny, albowiem autor odwołuje się do zapisu

Reports and reviews biblijnego Starego Testamentu jako źródła zapowiadającego sakrament Eucharystii, aby poprzez odniesienia do Nowego Testamentu ukazać jego urzeczywistnienie podczas Ostatniej Wieczerzy. Akcentuje odnośnie do ustanowienia Eucharystii dwie tradycje: Pawłowo-Łukaszowa i Markowo-Piotrową. Z wielu nazw odnoszących się do Eucharystii autor zwraca uwagę na ofiarę biesiadną, która podkreśla zarówno charakter ofiarniczy jak też dziękczynienia, a więc jedności pomiędzy ofiarą i ucztą. Eucharystia pomaga w budowaniu wspólnoty i przysposabia do rozumienia i praktykowania ducha służby w Kościele 
- co podkreśla Napiórkowski na zakończenie niniejszego rozdziału prezentowanej książki.

Autor wiele miejsca w swojej książce poświęca maryjnemu wymiarowi eklezjologii. Na podstawie wydarzenia Zwiastowania ukazuje objawienie proegzystencji Matki Boga, która służbą i ofiarnością jawi się jako wzór dla całego Kościoła. Ojciec Napiórkowski podejmuje również zagadnienie duchowości proegzystencji, która ma prowadzić do pokoju i jedności.

Godnym zauważenia i docenienia jest fakt, że Autor w swojej monografii ukazuje monastycyzm, jako ważny element w historiozbawczej eklezjologii. Zauważa, że u jego podstaw jest człowiek, który odczuwa wyraźne pragnienie osiągnięcia stanu duchowej komunii z Bogiem.

Warto zwrócić uwagę na fragment opisujący formy naśladowania Chrystusa, jakimi są wspólnoty zakonne i ich roli jaką odegrały w historii Kościoła. Również dziś klasztory jawią się jako miejsca cichej modlitwy, odkrywania harmonii świata, która w dobie „kultury hałasu” jest coraz mniej widoczna. Cały ruch pielgrzymkowy, nieodłącznie związany z klasztorami, był żywy na przestrzeni dziejów Kościoła i uczył pątników wchodzenia w liturgię, duchowość, a także rozwijał cnotę braterstwa.

Liturgia jak i teologia mnisza w maryjnym wymiarze stanowią ważną, a zarazem innowacyjną część tej książki. Autor ukazuje, że to Matka Boga inspiruje do całkowitego poświęcenia indywidualnego życia - Stwórcy. Maryja dla każdej osoby powołanej do stanu zakonnego jest niestrudzoną opiekunką i strażniczką charyzmatu i powołania. Tradycja chrześcijańska ukazuje Bogurodzicę jako nauczycielkę wartości, takich jak wierność, asceza, służba czy modlitwa.

Książka Proegzystencja Kościoła o. prof. Andrzeja Napiórkowskiego jest cenną publikacją, która w sposób bardzo przystępny i ciekawy podejmuje próbę opisania misji i istoty Kościoła. Już sam tytuł monografii zwraca uwagę każdego teologa zajmującego się tymi zagadnieniami. Autor opisując ważne zagadnienia odnosi je do współczesności, co jeszcze bardziej podnosi walory tej monografii. Na uwagę zasługuje również fakt, że książka ta to owoc osobistych i teologicznych przemyśleń autora. Publikacja zachęca czytelnika do indywidualnej refleksji na temat Kościoła, który w dzisiejszym świecie staje się jeszcze bardziej „znakiem sprzeciwu”. 